\title{
The Features of Reflexivity Development, Depended on Pupils' Personal Efficiency
}

\section{Особливості розвитку рефлексивності залежно від особистісної ефективності учнів}

Iryna Yavorska-Vietrova Ph.D. in Psychology, Senior Researcher of the Chamata Laboratory of Psychology of Personality
Ірина Яворська-Ветрова кандидат психологічних наук, старший науковий співробітник лабораторії психології особистості імені П. Р. Чамати

E-mail: irinavetrova009@gmail.com orcid.org/0000-0002-6509-930X

Researcher ID: G-4702-2018

\author{
G. S. Kostiuk Institute \\ of Psychology of NAPS \\ of Ukraine, Kyiv, Ukraine \\ 2, Pankivska street, \\ Kyiv, 01033
}

Інститут психології ілені Г. С. Костюка НАПН Украӥни, м. Київ, Україна вул. Паньківська, 2, м. Київ, 01033

Original manuscript received March 11, 2019 Revised manuscript accepted March 31, 2019

\begin{abstract}
The article examines reflexion as a determinant factor in personality formation that ensures activity successfulness, and reflexivity as a mechanism for personal efficiency formation. Reflexion is defined as an integrative property and a mechanism that enables a personality to realize and assess personal subjective qualities, to analyze personal "Me», to set new goals on the basis of personal meaningful assessments of own potentials, and, in conjunction with these goals, adjust adequately the perception of oneself and personal attitudes toward people around. The article describes the modern meta-cognitive
\end{abstract}


interpretations of reflexion as a rethinking of the contents of consciousness, which has regulatory functions.

The article analyzes data obtained from the experimental research on the types and properties of reflexivity, according to the criterion of its orientation (intra- and inter-psychic), characteristic for pupils with different efficiency during their transition from junior school age to adolescence. Pupils with high personal efficiency at stable, "uncritical» periods of school life demonstrate a sufficiently successful mastery of the ability to self-analysis, self-understanding, and understanding of their attitudes to others. At the same time, it has been found that the transitional periods (from primary to secondary school, from junior school age to adolescence) and the periods of adaptation show appearance of destructive tendencies, "blocking», and a decrease in the rate of reflexivity development, especially in the groups of low-efficiency pupils.

The article proves that pupils' intra-psychic reflexion is developed more intensively and constructively than inter-psychic during the period from the $3 r d$ to 6th school years. This general tendency is observed in both groups of pupils: with low and with high personal efficiency. The development of intrapsychic reflexion is intensified at the transition to adolescence, as evidenced by an increased number of indicators showing average and higher than the average levels of this type of reflection, especially in groups of pupils with average and high-efficient levels.

Key words: reflexion, reflexivity, personal efficiency, intra-psychic reflexion, inter-psychic reflexion, psychological mechanism.

\section{Вступ}

Сучасний етап трансформації освітнього вітчизняного простору актуалізує проблему розвитку самосвідомості, саморозуміння особистості, формування їі ціннісного ставлення до самої себе, сприйняття себе як успішного, ефективного суб'єкта життєдіяльності. Усвідомлення дитиною самої себе, формування позитивного ставлення до себе, оцінка власних досягнень і потенційних можливостей досягнення успіху справляють значний вплив на її поведінку й успішність учіннєвої діяльності - зокрема, у молодшому шкільному віці. Адекватні уявлення школяра про самого себе як суб’єкта учіннєвої діяльності, навколишній світ, аперцепція інших людей і взаємини з ними, несуперечлива інтерпретація набутого досвіду i власне усебічний роз- 
виток розуміння себе є підгрунтям становлення здатності до регулювання поведінки і діяльності, високих очікувань дитини щодо самої себе, її успішності загалом. Розвивальна парадигма сучасної освіти грунтується на врахуванні внутрішніх інтенцій школяра, починаючи з перших етапів учіннєвої діяльності. Значущою передумовою успішності процесу становлення особистісної ефективності дитини є їі адаптація до умов навчання на різних його щаблях. Тому важливим $є$ вивчення психологічних механізмів становлення особистісної ефективності не лише на першому етапі навчання - у початковій школі, але й також у перехідний період від початкової до основної школи, від молодшого шкільного до підліткового віку. В якості такого механізму ми розглядаємо рефлексивність, важливість якої зростає на цьому етапі онтогенезу, оскільки зміна соціальної ситуації розвитку, нові умови учіннєвої діяльності та спілкування сприяють становленню у дітей рефлексивного переходу «від уявлень про себе до думки про себе» (П. Р. Чамата).

Сучасні уявлення про успішну, творчу, ефективну особистість коригуються з положеннями суб'єктного підходу до становлення особистості на різних етапах їі онтогенезу (Гуляс, 2018; Дригус, 2015; Ільїна, 2009; Мусіяка, 2018; Татенко, 2005). Так, із рефлексивністю як «здатністю свідомості звернутися на самого себе як носія свідомості», на думку О. М. Анісімової, тісно пов'язане розуміння себе, саморозуміння. Авторка визначає рефлексивність як якість, що дає змогу особистості «зрозуміти й оцінити себе» (Анисимова, 2013: 122). Але усвідомлювана інформація може бути як чинником внутрішньоособистісного дисбалансу, так i чинником удосконалення себе i своєї життєдіяльності. Проведене під керівництвом О. М. Анісімової дослідження показало, що рефлексивність включається в саморегуляцію поведінки і сприяє самореалізації особистості за умови, якщо центральними у її (особистості) структурі виступають такі риси, як «самоприйняття, самоповага, впевненість у собі, самостійність, автономність, інтенціональ- 
ність - низка якостей, що охоплюється поняттям суб'єктності. Особистість такого складу відзначається здатністю робити правильні життєві вибори на основі розуміння себе і довіри до себе» (Анисимова, 2013: 123-124).

У контексті нашого дослідження важливим є розуміння особистості «як унікальної цілісності, що саморозвивається, саморегулюється і є носієм довічного вселюдського духу» (Максименко, 2014: 20), а також тих психологічних механізмів, що зумовлюють особистісний розвиток (Максименко, 2018; Дригус, 2015; Кондратенко, 2017). С. Д. Максименко виокремлює такі три рівні розвитку особистості: «на першому рівні ще відсутня рефлексія власного внутрішнього світу, який лише формується, створюється; на другому рівні розвитку особистість формує власне оточення, передбачає наслідки і планує події; на третьому рівні особистість стає суб'єктом власного життєвого шля$\mathrm{xy}$, який вона сама обирає. Інша ознака цього рівня - особистість стає суб'єктом розвитку свого власного внутрішнього світу, формує власне «Я». Саме на цьому рівні основною стає якість унікальності» (Максименко, 2011: 9-10). На думку С. Д. Максименка, рефлексія виступає стрижневим механізмом розвитку особистості: «3 цього моменту людина сама визначає напрями власного розвитку, контролює його і несе за нього відповідальність. Це є те, що в сучасній психології називають саморозвитком» (Максименко, 2006: 96). Учений наголошує, що психічний розвиток тільки тоді стає розвитком особистості, коли він є й «рефлексією людиною власного досвіду» .

Нині на підгрунті положень С. Л. Рубінштейна про «вторинність» рефлексії при «зверненні свідомості зі світу, що пізнається у відчуттях, уявленнях, на них самих» розробляються сучасні метакогнітивістичні трактування рефлексії як переосмислення змістів свідомості, що має регулюючі функції (Карпов, 2013; Литвинов, Иволина, 2013; Ivashkevych, Onufriieva, 2018). Зокрема, А. В. Карпов розглядає рефлексію як «складний високоорганізований мета- 
когнітивний процес» . Проведене ним емпіричне дослідження структури рефлексії показало, що «рефлексивні процеси виступають продуктами, результатами закономірної співорганізації, структурування, інтеграції окремих метапроцесів. На рівні їх структури, тобто на «рівні цілого», виникають ті нові, синергетичні відносно простого агрегування метапроцесів ефекти і якості, закономірності й особливості, специфічні саме для рефлексії» (Карпов, 2013: 172).

Зарубіжні дослідники вважають рефлексивність базовим регулятивним компонентом метакогніції, здатністю до моніторингу і контролю розумових дій (Hacker, Bol \& Keener, 2008). D. Marks-Maran i P. Rose описують три мети рефлексії: перевизначити (ре-дефінувати) наше розуміння знань, для розвитку особистих знань або самосвідомості, для оцінки доречності наших дій. T. Ghaye i S. Lillyman припускають, що рефлексія може діяти як міст від мовчазного знання до продуманої дії, як украй необхідний контрдискурс, щоб дати нам змогу поставити під сумнів нашу усталену «мудрість» (Forrest, 2008). J. Moon розробила практику «рефлексивного писання» : коли студентам після коротких курсів пропонувалося «зупинитися і подумати», записати свої роздуми щодо отриманих знань із метою встановлення зв'язку між новими знаннями і поточною робочою ситуацією (Moon, 1999). Проведені B. Vachon i J. LeBlanc дослідження довели, що застосування такої методики підвищує мотивацію учнів до самооцінки, сприяє збільшенню їх самоефективності й саморегуляції. В. Larrivee вважає, що педагогічна практика може бути перетворена за допомогою рефлексивної практики, стверджуючи, що «критична рефлексія - це не тільки спосіб наблизитися до викладання, але й спосіб життя» (Larrivee, 2000: 306).

Розглядаючи свідомість як багатофункціональну буттєвість, що забезпечує «не лише відображення дійсності, а й породження смислів, значень і цінностей, актуалізацію пізнавальних, почуттєвих, інтенційних, інтуїтивних та інших психоформ (особистісні переживання, думки, зна- 
ння)», А. В. Фурман зауважує, що інтенційність свідомості «уможливлює рефлексування в актах самоусвідомлення, Я-концептуалізації (Фурман, 2017: 6-7). На інтегративній ролі рефлективності наголошує О. Я. Фенина: базовий інтегративний характер рефлексії в розвитку всіх компонентів саморегуляції дає змогу розглядати її як детермінуючий чинник становлення особистості, що забезпечує успіх діяльності (Фенина, 2017: 288-289). Рефлексивність як здатність особистості «до спрямування власної діяльності на саму себе», яка «забезпечує особистості можливість самоконструювання, саморозвитку, самодетермінації» (Леонтьєв, 2009; Заїка, 2014) перебуває у взаємовпливі й взаємозалежності з особистісною ефективністю школярів, виступаючи механізмом її становлення.

Аналіз теоретико-експериментальних досліджень дає підстави констатувати, що рефлексія розглядається як інтегративна властивість і механізм, який дає змогу особистості усвідомити, пізнати й оцінити свої суб'єктні якості, проаналізувати власне «Я» та на основі особистісно-смислової оцінки своїх потенційних можливостей поставити нові цілі й співставно з ними адекватно коригувати уявлення про себе і свої стосунки з оточуючим світом. Водночас нині недостатньо дослідженим залишається питання становлення рефлексивності в учнів із різною особистісною ефективністю на етапі переходу від молодшого шкільного до підліткового віку.

Мета статті - здійснити аналіз експериментальних даних дослідження типів рефлексивності, а також властивостей рефлексивності за критерієм спрямованості в учнів різних за ефективністю груп на межі переходу від молодшого шкільного до підліткового віку.

\section{Задання статті}

1. Установити тенденції макрогенези динаміки розвитку рефлексивності у школярів різних за особистісною ефективністю груп. 
2. Виявити особливості інтра- й інтерпсихічної рефлексії у школярів 3-6-х класів із різною особистісною ефективністю.

\section{Методи та методики дослідження}

Концептуальний підхід до архітектоніки проведення експериментального дослідження розроблено М. Т. Дригус (Дригус, 2015, 2017). Аналіз результатів вивчення рефлексивності як механізму особистісної ефективності учнів здійснювався у площинах мікро- та макрогенези з метою 3'ясування тенденцій становлення рефлексивності як на певному етапі навчання, так і в межах кожного рівня особистісної ефективності упродовж певного періоду навчання школярів у початковій і основній школі. У дослідженні брали участь учні 3-6-х класів (129 осіб). За експертною оцінкою вчителів школярів було поділено на три групи відповідно до рівня їх особистісної ефективності (OE): I група - учні з високою особистісною ефективністю, II група учні з середньою особистісною ефективністю, III група учні з низькою особистісною ефективністю.

Вивчення становлення рефлексивності у школярів здійснювалося з використанням методики діагностики рівня рефлексивності А. В. Карпова, адаптованої для досліджуваної вікової категорії (Карпов, 1997). Вибір методики визначався теоретичними положеннями про те, що рефлексія як інтегративна психічна реальність проявляється у взаємопов'язаних і взаємодетермінованих модусах: рефлексивність як психічна властивість, рефлексія у iï процесуальному статусі й рефлексування як особливий психічний стан. Тому запропонована методика орієнтована на дослідження не тільки безпосередньо рефлексивності як психічної властивості, а й ураховує поведінкові й інтроспективні індикатори, у яких конкретизуються теоретичні конструкти і рефлексії як процесу, і рефлексування як психічного стану. Крім того, методика дає змогу дослі- 
дити рівні розвитку рефлексивності за критерієм спрямованості (інтра- й інтерпсихічна). Виступаючи найбільш інтегрованим процесом, «рефлексія водночас є способом і механізмом виходу системи психіки за особистісні межі, що детермінує пластичність і адаптивність особистості» (Карпов, 2002: 283).

Методика включає 27 тверджень, 15 із яких є прямими, 12 - оберненими. За результатами обробки отриманих даних було виокремлено три рівні розвитку рефлексивності: низький, середній і з тенденцією до високого (оскільки стабільного високого рівня розвитку рефлексивності у школярів зазначених вікових груп виявлено не було, а результати деякої кількості учнів зафіксовано у діапазоні перехідних балів (стенів) від середнього до високого рівня, на нижній межі показників високого рівня). Порівняльний аналіз вибіркових середніх за t-критерієм Стьюдента показав статистично значущі відмінності за виокремленими показниками.

\section{Результати та дискусії}

Аналіз макрогенези динаміки розвитку рефлексивності у школярів різних за ефективністю груп показав таке. На діаграмі (рис. 1) подано результати дослідження динаміки показників рівнів розвитку рефлексивності у групах низькоефективних учнів 3-6-х класів.

Отримані результати свідчать про те, що у низькоефективних учнів від третього до шостого класу констатовано тільки низький і середній рівні розвитку рефлексивності. Тенденції до високого рівня розвитку рефлексивності у цій групі школярів виявлено не було. При цьому спостерігається обернено пропорційна динаміка низького і середнього рівнів розвитку рефлексивності (окрім 5-го класу): від $85,7 \%$ показників низького рівня у третьокласників до $42,9 \%$ - у шестикласників і від 14,3\% показників високого рівня у третьокласників до $57,1 \%$ - у шестикласників. 


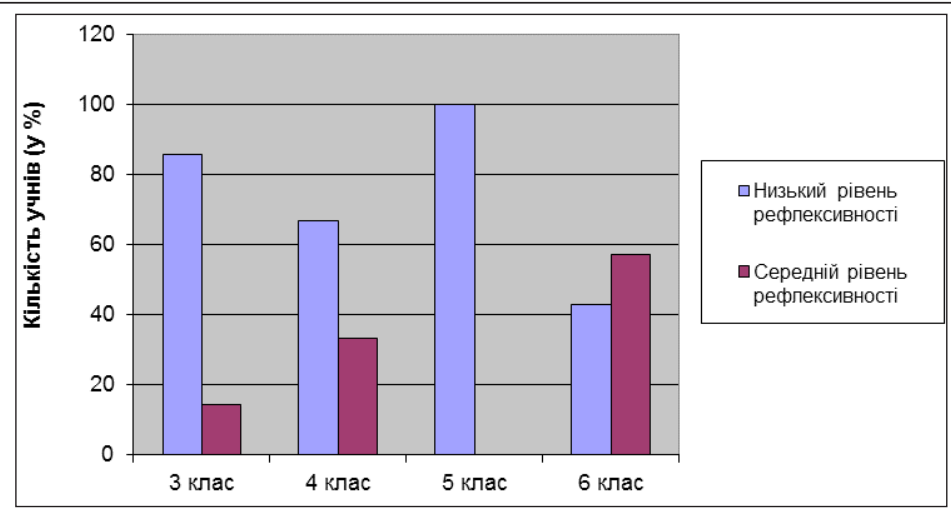

Рис. 1. Показники розподілу рівнів розвитку рефлексивності в учнів $3-6$-х класів із низькою ОЕ

Низькоефективні учні 5-го класу 100-відсотково продемонстрували низький рівень розвитку рефлексивності, що пов'язано, на нашу думку, з особливостями соціальної та особистісної ситуації розвитку дітей цієї вікової групи. Зокрема, перехід до основної школи, що відбувся, необхідність адаптації до нових умов навчання, а також перехід до нового вікового етапу розвитку з початком відповідної фізіологічної, соціально-рольової, особистісної перебудови впливають на становлення самосприймання, саморозуміння, самоусвідомлення дітей. Тому можна говорити про певний «збій», деструкцію у системі уявлень про власне «Я» п'ятикласників. Загалом же розвиток рефлексивності як здатності до самоаналізу, розуміння й осмислення власного «Я», своїх емоційних, поведінкових і міжособистісних проявів у низькоефективних учнів співвідноситься з віковими параметрами, тобто чим старшими стають діти цієї групи, тим вищим є рівень оволодіння ними такими діями (при цьому навіть серед шестикласників учнів із середнім рівнем розвитку рефлексивності трохи більше половини). П'ятикласники з низькою ОЕ потребують особливої уваги вчителів і психологів, оскільки їх здатність до саморозуміння й самоаналізу переживає деструкцію. 
Динаміку показників рівнів розвитку рефлексивності середньоефективних учнів 3-6-х класів подано на діаграмі (рис. 2).

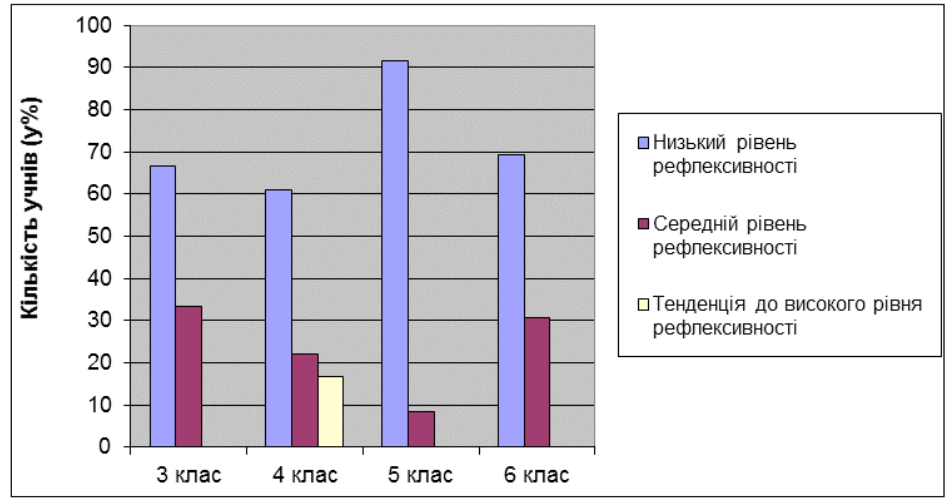

Puc. 2. Показники розподілу рівнів розвитку рефлексивності в учнів 3-6-х класів із середньою ОЕ

Школярі цієї групи успішності продемонстрували як низький і середній рівні розвитку рефлексивності, так і тенденцію до високого рівня (четвертокласники). Особливістю учнів із середньою ОЕ усіх класів, що досліджувалися, $€$ наявність стабільно великої кількості показників низького рівня розвитку рефлексивності: 66,7\% у третьокласників, 61,1\% у четвертокласників, 91,7\% у п'ятикласників і $69,2 \%$ у шестикласників. При цьому показники середнього рівня зменшуються від 3-го до 5-го класу $(33,3 \%, 22,2 \%$ і 8,3\% відповідно у третьому, четвертому і п'ятому класах) і тільки у шестикласників знову підвищуються до 30,8\% . Отже, у середньоефективних учнів від третього до шостого класів зберігається тенденція співвіднесення низького і середнього рівнів розвитку рефлексивності у пропорції «дві третини до однієї третини», набуваючи максимальних розбіжностей у п'ятикласників: $91,7 \%$ і 8,3\% відповідно. Поява тенденції до високого рівня розвитку рефлексивності пов'язана, на нашу думку, з індивідуально-особистісни- 
ми особливостями частини середньоефективних четвертокласників і є, скоріше за все, винятком із загальної картини динаміки розвитку рефлексивності у школярів цієї групи успішності.

Аналіз динаміки показників рівнів розвитку рефлексивності у високоефективних учнів 3-6-х класів показав таке (рис. 3).

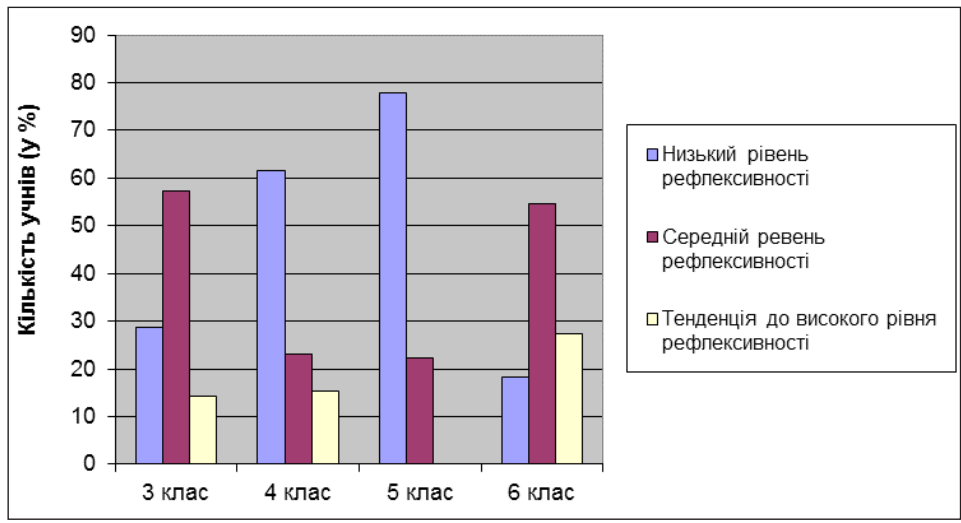

Pис. 3. Показники розподілу рівнів розвитку рефлексивності в учнів 3-6-х класів із високою ОЕ

Отримані результати демонструють збільшення кількості високоефективних школярів (окрім 5 класу), що виявили тенденцію до високого рівня розвитку рефлексивності від третього до шостого класу: $14,3 \%$ третьокласників, 15,4\% четвертокласників і 27,3\% шестикласників. Особливості цих учнів полягають у тому, що полярні за віком групи школярів (третьокласники і шестикласники) показали подібні результати, а саме: переважання, порівняно з низьким, середнього рівня розвитку рефлексивності (57,1\% і 54,6\% відповідно), наявність тенденції до високого рівня розвитку рефлексивності (14,3\% і 27,3\% відповідно). При цьому високоефективні школярі 4-го і 5-го класу показали практично однакові результати із середньоефективними учнями цих самих вікових груп (див. 
рис. 2 і рис. 3). Такі дані дають підстави для певних висновків. Учні з високою ОЕ у стабільні, «некритичні» періоди шкільного життя демонструють достатньо успішне оволодіння здатністю до самоаналізу, саморозуміння, осмислення себе і своїх ставлень з оточуючими. Водночас перехідні періоди (від початкової до основної школи, від молодшого шкільного до молодшого підліткового віку) та періоди адаптації (до нових умов навчального процесу, змін як внутрішніх - фізіологічних, психологічних, так і зовнішніх - соціальних, рольових, міжособистісних) викликають деструктивні тенденції, певне «блокування», зниження темпів розвитку рефлексивності у цієї групи школярів.

Одним з аспектів аналізу є дослідження властивості рефлексивності за критерієм спрямованості. Відповідно до нього виокремлюють два типи рефлексії: «інтра-» й «інтерпсихічну» (А. В. Карпов). Перша співвідноситься з рефлексивністю як здатністю до самосприймання змісту власної психіки і його аналізу, а друга - зі здатністю до розуміння психіки інших людей, що включає як здатність стати на місце іншого, так і механізми проекції, ідентифікації, емпатії.

За даними дослідження інтра- й інтерпсихічної рефлексії у школярів 3-6-х класів було виокремлено п'ять рівнів їх прояву: низький, нижчий від середнього, середній, вищий від середнього, високий. Необхідність такого поділу зумовлена тим, що як у різних вікових групах, так і в різних групах за ефективністю була зафіксована значна кількість межових, перехідних показників рівнів розвитку обох типів рефлексії. Тобто, можна стверджувати про досить чітко виявлені тенденції становлення у певному віковому періоді тієї чи тієї спрямованості рефлексії.

Аналіз макрогенези типів рефлексії в учнів від 3-го до 6-го класу різних за ефективністю груп показав таке. У групі учнів із низькою ОЕ (рис. 4, рис. 5) від 3-го до 5-го класу зростають показники середнього рівня інтрапсихічної рефлексії. 


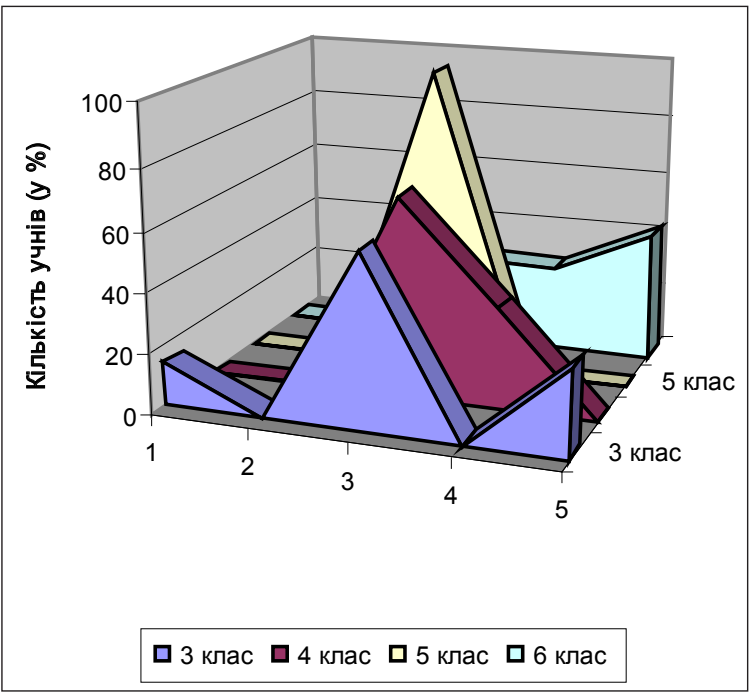

Puc. 4. Показники рівнів інтрапсихічної рефлексії в учнів 3-6-х класів із низькою ОЕ

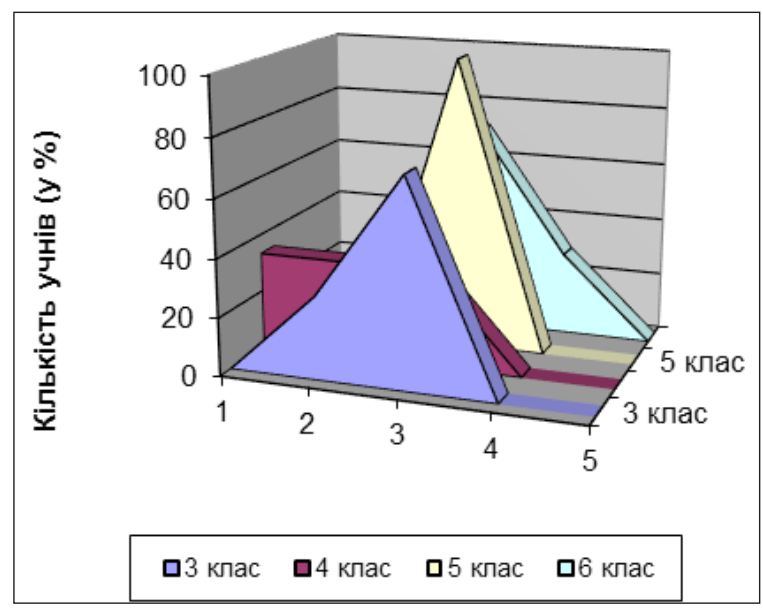

Puc. 5. Показники рівнів інтерпсихічної рефлексії в учнів 3-6-х класів із низькою ОЕ

Прилітка: 1 - низький рівень; 2 - нижчий за середній рівень; 3 - середній рівень; 4 - вищий за середній рівень; 5 - високий рівень. 
При цьому тільки третьокласники цієї групи виявили низький її рівень, а п'ятикласники - тільки середній. Простежується тенденція розвитку здатності до саморозуміння й самоаналізу в цих школярів у онтогенезі: від 28,6\% високого рівня у третьокласників, 33,3\% вищого від середнього рівня у четвертокласників до 28,6 \% вищого від середнього і 42,9\% високого рівнів у шестикласників. Такі дані дають змогу зробити висновок про те, що становлення інтрапсихічної рефлексії у низькоефективних молодших школярів є достатньо стабільним і має тенденцію до підвищення при переході до підліткового віку. Щодо інтерпсихічної рефлексії, то на підставі одержаних результатів дослідження можна констатувати, що за досить високих показників середнього рівня її розвитку (3-й клас - 71,4\%, 4-й клас $33,3 \%, 5$-й клас $-91,7 \%, 6$-й клас - 71,4\% ) в учнів із низькою ОЕ не зафіксовано показників високого рівня, а вищий від середнього рівень виявили тільки близько третини шестикласників. При цьому учні молодшого шкільного віку показали нижчий від середнього (3-й клас $-28,6 \%, 4$-й клас $-33,3 \%$ ) і низький (4-й клас - 33,3\% ) рівні інтерпсихічної рефлексії. Тобто, розвиток здатності до розуміння інших, становлення механізмів проекції та ідентифікації у школярів цієї групи переживає певну деструкцію на межі молодшого шкільного та підліткового віку.

Учні з середньою ОЕ у сфері інтрапсихічної рефлексії продемонстрували такі результати (рис. 6). На відміну від низькоефективних, школярі цієї групи виявили низький (5-й клас $-8,3 \%)$ і нижчий від середнього (3-й клас-33,3\% , 6 -й клас $-7,7 \%$ ) рівні цього типу рефлексії. При цьому до тенденції до зростання показників середнього рівня додається виразна тенденція наявності в усіх вікових групах показників вищого від середнього (3-й клас - 16,7\%, 4-й клас $-5,6 \%, 5$-й клас $-8,3 \%, 6$-й клас $-7,7 \%$ ) і високого (3-й клас - 16,7\%, 4-й клас - 33,3\%, 6-й клас - 15,4\%) рівнів інтрапсихічної рефлексії. Отже, здатність до саморозуміння й самоаналізу в учнів із середньою ОЕ за певної ди- 

фузності, «розсіяності» має достатньо стабільну тенденцію до підвищення її показників від 3-го до 6-го класу.

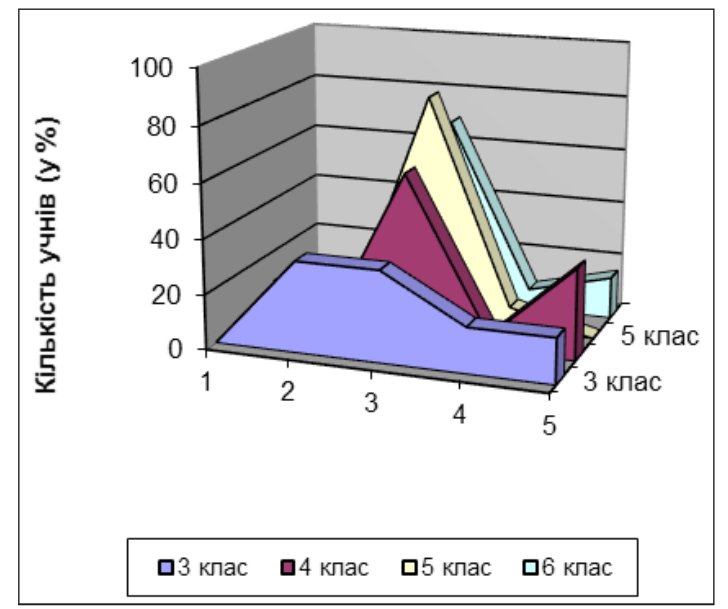

Puc. 6. Показники рівнів інтрапсихічної рефлексії в учнів 3-6-х класів із середньою ОЕ

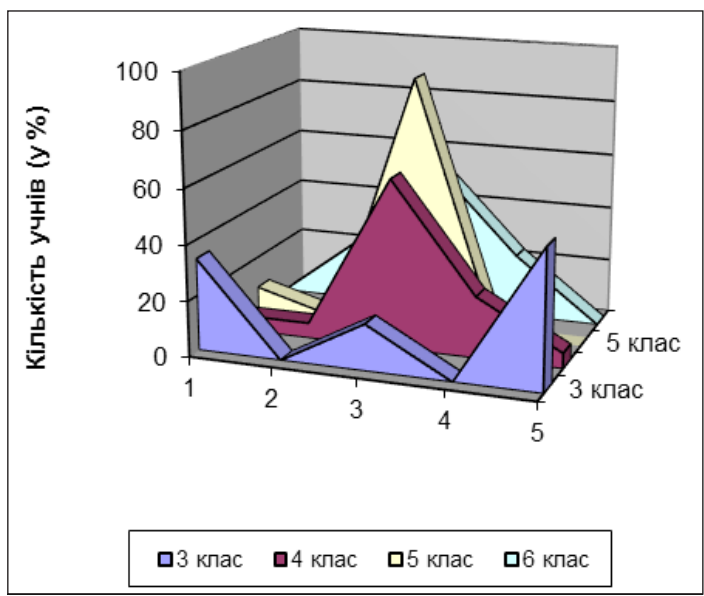

Puc. 7. Показники рівнів інтерпсихічної рефлексії в учнів 3-6-х класів із середньою ОЕ

Примітка: 1 - низький рівень; 2 - нижчий за середній рівень; 3 - середній рівень; 4 - вищий за середній рівень; 5 - високий рівень. 
Розвиток інтерпсихічної рефлексії у середньоефективних учнів (рис. 7) має свої особливості. При зростанні від 3-го до 6-го класу і певній стабілізації показників середнього рівня інтерпсихічної рефлексії зафіксовано зниження та відсутність показників високого (3-й клас - 50,0\%, 4 -й клас - 5,6\%, 5-й і 6-й класи - не виявлено) і вищого від середнього (4-й клас - 22,2\%, 6-й клас - 23,1\%, 3-й і 5-й класи - не виявлено) рівнів цього типу рефлексії. При цьому в усіх вікових групах наявні показники низького (3-й клас $-33,3 \%, 4$-й клас - 5,6\%, 5-й клас - 8,3\% ) та нижчого від середнього (4-й клас - 5,6\%, 6-й клас - 23,1\% ) рівнів інтерпсихічної рефлексії. Тобто, можна констатувати, що від третини у третьому класі до $1 / 5$ школярів із середньою OE у шостому класі мають труднощі у розвитку здатності розуміти дії й почуття інших людей, виявляти емпатію, ставати на місце іншого.

Дані дослідження свідчать, що така ситуація змінюється з підвищенням рівня ефективності учнів. Так, учні першої групи (рис. 8 і рис. 9) як у сфері інтер-, так і - особливо - у сфері інтрапсихічної рефлексії продемонстрували значне збільшення показників високого і вищого від середнього рівнів. Зокрема, тільки у високоефективних четвертокласників виявлено низький рівень обох типів рефлексії (по 7,7\%), в інших вікових групах ні низького, ні нижчого від середнього рівнів не зафіксовано. При цьому в сфері інтрапсихічної рефлексії учні зазначеної групи показали збільшення показників вищого від середнього рівня (4-й клас - 15,4\%, 5-й клас - 22,2\%, 6-й клас-27,3\%) і стабільно значні показники високого рівня цього типу рефлексії: 3 -й клас - 57,1\%, 4-й клас - 38,5\%, 5-й клас $55,6 \%, 6$-й клас - 54,6\%. Отже, від половини до $80 \%$ досліджуваних високоефективних учнів мають достатньо розвинену здатність до сприймання власних внутрішніх інтенцій, розуміння й аналізу своїх переживань і дій. 


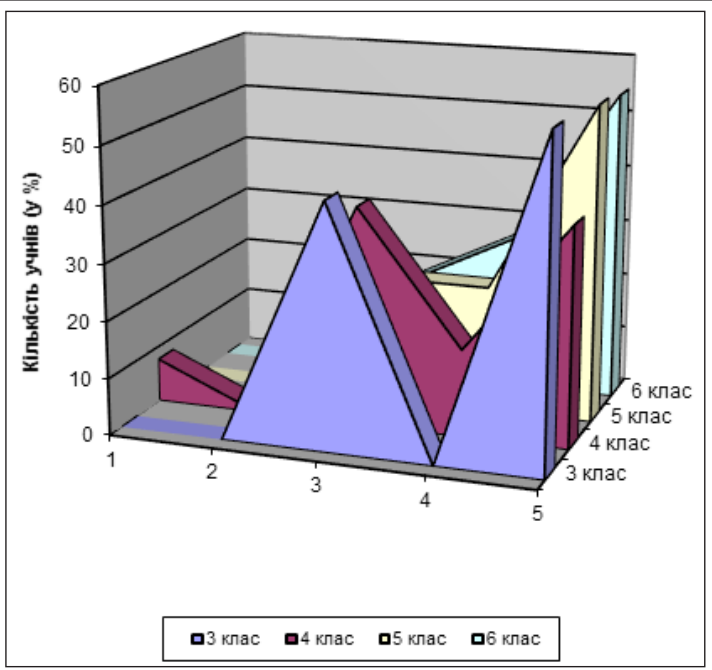

Puc. 8. Показники рівнів інтрапсихічної рефлексії в учнів $3-6$-х класів із високою ОЕ

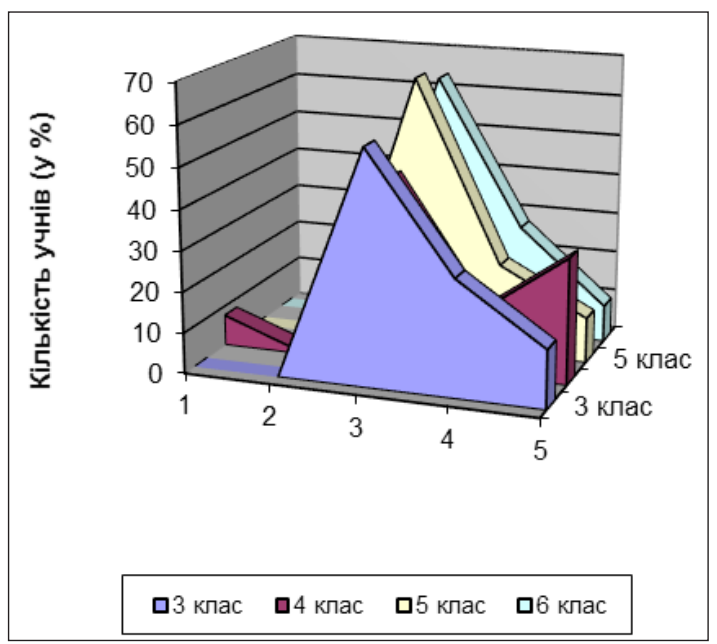

Puc. 9. Показники рівнів інтерпсихічної рефлексії в учнів 3-6-х класів із високою $\mathrm{OE}$

Примітка: 1 - низький рівень; 2 - нижчий за середній рівень; 3 - середній рівень; 4 - вищий за середній рівень; 5 - високий рівень. 
Показники у сфері інтерпсихічної рефлексії у школярів першої групи дещо відрізняються, але загалом демонструють достатньо конструктивне становлення. Як уже зазначалося, у цій групі (крім 4-го класу) не виявлено показників низького і нижчого від середнього рівнів цього типу рефлексії. Практично більше половини високоефективних учнів мають середні показники: 3-й клас - 57,1\%, 4-й клас $-46,2 \%, 5$-й клас - 66,7\% , 6-й клас - 63,6\% . При цьому хоча кількість учнів із високим рівнем інтерпсихічної рефлексії зменшується (3-й клас - 14,3\%, 4-й клас $30,8 \%, 5$-й клас - 11,1\%, 6-й клас - 9,1\% ), показники вищого від середнього рівня залишаються досить стабільними: 3-й клас - 28,6\%, 4-й клас - 15,4\%, 5-й клас $-22,2 \%$, 6 -й клас - 27,3\%. Такі дані свідчать про те, що здатність до розуміння інших, механізми проекції, ідентифікації, емпатія у школярів із високою ОЕ конструктивно розвиваються, переживаючи деяку деструкцію при переході до підліткового віку, під час адаптації до основної школи.

\section{Висновки}

Одержані результати дослідження розвитку рефлексивності школярів 3-6-х класів усіх груп за ефективністю свідчать про те, що саме розвиток здатності до осмислення свого «Я», своїх внутрішніх інтенцій і взаємин з оточуючими, тобто розвиток властивостей рефлексивності, є одним зі шляхів успішного подолання критичних, адаптаційних і перехідних періодів у житті школяра, механізмом його особистісного зростання.

На підставі аналізу одержаних даних можна стверджувати, що інтрапсихічна рефлексія у школярів від 3-го до 6-го класу розвивається більш інтенсивно і конструктивно, ніж інтерпсихічна. Така загальна тенденція спостерігається як у групах учнів із низькою, так і з високою ОЕ. При цьому певну деструкцію становлення здатності до самосприймання і саморозуміння зафіксовано у перехідний період, під час адаптації дітей до нових умов навчання i 
розвитку, що особливо виразно проявляється у низькоефективних п'ятикласників i середньоефективних учнів 4-6-х класів. Розвиток інтерпсихічної рефлексії інтенсифікується на межі переходу до підліткового віку, особливо у середньо- та високоефективних учнів, про що свідчить збільшення кількості показників середнього і вищого від середнього рівнів цього типу рефлексії у вказаних школярів. При цьому якщо третина третьокласників і дві третини четвертокласників із низькою ОЕ відчувають труднощі у розумінні інших, то вже у п'яти- і шестикласників цієї групи низьких і нижчих від середнього показників не зафіксовано. Тобто, на межі підліткового віку інтенсифікується інтерес до себе, свого внутрішнього світу, а також на перший план починає виступати інтерперсональна взаємодія як у сфері навчальної діяльності, що залишається важливою (особливо для четвертокласників), так і у сфері міжособистісних взаємин.

\section{Література}

Анисимова О. М. Самопонимание - важнейший аспект субъектности. Человек, субъект, личность в совреленной психологии: Материалы Международной конференции, посвященной 80-летию А. В. Брушлинского. Т. 2 / Отв. ред. А. Л. Журавлев, Е. А. Сергиенко. Москва : Изд-во ИП РАН, 2013. С. 121-124.

Гуляс I. А. ЖҺиттєвий успіх як соціально-психологічний феномен. Проблели сучасної психології: Збірник наукових праць Кам'янецьПодільського національного університету ілені Івана Огієнка, Інституту психологї ілені Г. С. Костюка НАПН України / За наук. ред. С. Д. Максименка, Л. А. Онуфрієвої. Кам'янецьПодільський : Аксіома, 2018. Вип. 41. С. 69-78. DOI 10.32626/ 2227-6246.2018-41.69-78.

Дригус М. Т. Концептуальні парадигми самоефективності особистості. Актуальні проблели психологї: Збірник наукових пращь Інституту психологї ілені Г. С. Костюка НАПН України. Київ : Видавництво «Фенікс», 2017. Т. ХІІ. Психологія творчості. Вип. 23. C. 88-97.

Заїка С. В., Зімовін О. І. Рефлексивність особистості як предмет психологічного пізнання. Психологія і суспільство. 2014. №. 2. С. 9097. 
Ivashkevych E., Onufriieva L. Social Intelligence in the Paradigm of Cognitive Psychology: the Results of Study. Проблели сучасної психологї: Збірник наукових праць Кал'янець-Подільського національного університету ілені Івана Огієнка, Інституту психології ілені Г. С. Костюка НАПН України / За наук. ред. С. Д. Максименка, Л. А. Онуфрієвої. Кам'янець-Подільський : Аксіома, 2018. Вип. 42. С. 50-69. DOI 10.32626/2227-6246.2018-42.50-69.

Ільїна Ю. М. Науковий огляд проблематики успіху та успішності. Актуальні проблели психологї: Психологічна теорія і технологія навчання / За ред. С. Д. Максименка, М. Л. Смульсон. Київ : Видво НПУ імені М. П. Драгоманова, 2009. Т. 8. Вип. 6. С. 98-112.

Карпов А. В. Закономерности организации метакогнитивных и метарегулятивных процессов в структуре рефлексии. Человек, субъект, личность в совреленной психологии: Материалы Международной конференции, посвященной 80-летию А. В. Брушлинского. Т. 2 / Отв. ред. А. Л. Журавлев, Е. А. Сергиенко. Москва : Изд-во ИП PAH, 2013. С. 169-173.

Карпов А. В., Скитяева И. М. Психология рефлексии. Москва - Ярославль : Аверс Пресс, 2002. 304 с.

Кондратенко Л. О. Психологія первинної шкільної неуспішності: монографія. Чернігів : Десна Поліграф, 2017. 488 с.

Леонтьев Д. А. Рефлексия как предпосылка самодетерминации. Психология человека в совреленнол лире: Материалы Всероссийской юбилейной научной конференции, посвященной 120-летию со дня рождения С. Л. Рубинштейна (Москва, 15-16 октября 2009 г.) / Отв. ред. А. Л. ЖЖуравлев и др. Москва : Изд-во ИП РАН, 2009. T. 2. C. 40-49.

Литвинов А. В., Иволина Т. В. Метакогниция: понятие, структура, связь с интеллектуальными когнитивными способностями (по материалам зарубежных исследований) [Электронный ресурс]. Coвреленная зарубежная психология. 2013. № 3. С. 59-70. Режим доступа : http://psychlib.ru/mgppu/periodica/SZP032013/szp0591.htm\#\$p59.

Максименко С. Д. Генеза здійснення особистості. Київ : Видавництво $\mathrm{TOB} « \mathrm{KMM} », 2006.240 \mathrm{c}$.

Максименко С. Д. Механізми розвитку особистості. Проблели сучасної психологї: Збірник наукових праць Кал'янець-Подільського наиіонального університету ілені Івана Огієнка, Інституту психологї ілені Г. С. Костюка НАПН України / За ред. С. Д. Максименка, Л. А. Онуфрієвої. Кам’янець-Подільський : Аксіома, 2018. Вип. 40. С. 7-23. DOI 10.32626/2227-6246.2018-40.7-23.

Максименко С. Д. Психологічні механізми становлення та здійснення особистості. Проблели сучасної психологї: Збірник наукових 
праць Кал'янець-Подільського національного університету ілені Івана Огієнка, Інституту психологї ілені Г. С. Костюка НАПН України / За ред. С. Д. Максименка, Л. А. Онуфрієвої. Кам'янецьПодільський : Аксіома, 2011. Вип. 11. С. 3-11.

Мусіяка Н. І. Розвиток творчого мислення як особистісної детермінанти навчальних досягнень молодших школярів. Проблели сучас ної психології: Збірник наукових праць Кам'янець-Подільського національного університету ілені Івана Огієнка, Інституту психологї ілені Г. С. Костюка НАПН України / За наук. ред. С. Д. Максименка, Л. А. Онуфрієвої. Кам'янець-Подільський : Аксіома, 2018. Вип. 41. С. 205-217. DOI 10.32626/2227-6246.201841.205-217.

Становлення особистісної ефективності учнів в онтогенетичному виміpi: монографія / Г. О. Балл, М. Т. Дригус, Н. І. Мусіяка, І. В. Яворська-Ветрова; за ред. М. Т. Дригус. Київ : Педагогічна думка, 2015. $161 \mathrm{c}$.

Татенко В. О. Суб'єктно-вчинкова традиція в реформуванні освіти. Теоретико-летодологічні проблели розвитку особистості в систелі неперервної освіти: Матеріали методологічного семінару АПН України (16 грудня 2004 року); за ред С. Д. Максименка. Київ , 2005. С. 248-256.

Фенина О. Я. Проблема рефлексії та рефлективності особистості у становленні професійного самоменеджменту. Психологія: реальність і перспективи: Збірник наукових праць РДГУ. 2017. Вип. 8. C. 286-291.

Фурман А. В. Свідомість як передумова психологічного пізнання і професійного методологування. Наука і освіта. Психологія. 2017. № 3. C. 5-10. DOI http://doi.org/10.24195/2414-4665-2017-3-1.

Энциклопедия психологических тестов: Общение, лидерство, межличностные отношения / Под ред. А. Карелина. Москва : АСТ, 1997. 303 c.

Forrest, M. E. S. (2008). On becoming a critically reflective practitioner. Health Information and Libraries Journal, 25, Issue 3, 229-232. Retrieved from https://doi.org/10.1111/j.1471-1842.2008.00787.x.

Hacker, D. J., Bol, K., \& Keener, M. C. (2008). Metacognition in Education: A Focus on Calibration. Handbook of Memory and Metacognition. Mahwah, NJ : Lawrence Erlbaum Associated. P. 429-456.

Larrivee, B. (2000). Transforming teaching practice: becoming the critically reflective teacher. Reflective Practice, 1, 293-307.

Moon, J. (2004). Reflection in Learning and Professional Development: Theory and Practice. London and New York : Routledge Falmer. 227 p.

Vachon, B., \& LeBlanc, J. (2011). Effectiveness of past and current critical incident analysis on reflective learning and practice change. Medi- 
cal Education, 45, Issue 9, 894-904. Retrieved from https://doi. org/10.1111/j.1365-2923.2011.04042x.

\section{References}

Anisimova, O. M. (2013). Samoponimanie - vazhnejshij aspekt sub'ektnosti [Self-understanding is the most important aspect of subjectivity]. A. L. Zhuravlev, E. A. Sergienko (Eds.). Chelovek, sub'ekt, lichnost' $v$ sovremennoj psihologii-Person, subject, personality in modern psychology: Proceedings of the International Conference dedicated to the 80th anniversary of $A$. V. Brushlinsky, 2, 121-124. Moskva : Izd-vo IP RAN [in Russian].

Hulias, I. A. (2018). Zhyttievyi uspikh yak sotsialno-psykholohichnyi fenomen [Life success as a socio-psychological phenomenon]. S. D. Maksymenko, L. A. Onufriieva (Eds.). Problemy suchasnoi psykholohii: Zbirnyk naukovukh prats Kamianets-Podilskoho natsionalnoho universytetu imeni Ivana Ohiienka, Instytutu psykholohii imeni H. S. Kostiuka NAPN Ukrainy - Problems of modern psychology: Collection of research papers of Kamianets-Podilskyi National Ivan Ohiienko University, G. S. Kostiuk Institute of Psychology of NAPS of Ukraine, 42, 69-78. Kamianets-Podilskyi : Aksioma. DOI 10.32626/2227-6246.2018-41.69-78 [in Ukrainian].

Dryhus, M. T. (2017). Kontseptualni paradyhmy samoefektyvnosti osobystosti [Conceptual paradigms of self-efficacy of personality]. Aktualni problemy psykholohii: Zbirnyk naukovukh prats Instytutu psykholohii imeni H.S. Kostiuka NAPN Ukrainy-Actual problems of psychology: Collection of research papers of G. S. Kostiuk Institute of Psychology of NAPS of Ukraine, 23, XVII, 88-97. Kyiv : Vydavnytstvo «Feniks» [in Ukrainian].

Zaika, Ye. V., \& Zimovin, O. I. (2014). Refleksyvnist osobystosti yak predmet psykholohichnoho piznannia [Reflexivity of the personality as an object of psychological knowledge]. Psykholohiia i suspilstvo Psychology and Society, 2, 90-97 [in Ukrainian].

Ivashkevych, E., \& Onufriieva, L. (2018). Social Intelligence in the Paradigm of Cognitive Psychology: the Results of Study. S. D. Maksymenko, L. A. Onufriieva (Eds.). Problemy suchasnoi psykholohii: Zbirnyk naukovukh prats Kamianets-Podilskoho natsionalnoho universytetu imeni Ivana Ohiienka, Instytutu psykholohii imeni H. S. Kostiuka NAPN Ukrainy - Problems of modern psychology: Collection of the research papers of Kamianets-Podilskyi National Ivan Ohiienko University, G. S. Kostiuk Institute of Psychology of NAPS of Ukraine, 42, 50-69. Kamianets-Podilskyi : Aksioma. DOI 10.32626/22276246.2018-42.50-69. 
Ilina, Yu. M. (2009). Naukovyi ohliad problematyky uspikhu ta uspishnosti [Scientific review of the problems of success and successful]. S. D. Maksymenko, M. L. Smulson (Eds.). Aktualni problemy psykholohii: Psykholohichna teoriia i tekhnolohiia navchannia - Actual problems of psychology: Psyhological Theory and Learning Techno$\log y, 8,6,98-112$. Kyiv : Vydavnytstvo NPU imeni M. P. Drahomanova [in Ukrainian].

Karpov, A. V. (2013). Zakonomernosti organizacii metakognitivnyh i metareguljativnyh processov v strukture refleksii [Patterns of the organization of metacognitive and metaregulative processes in the structure of reflexion]. A. L. Zhuravlev, E. A. Sergienko (Eds.). Chelovek, sub'ekt, lichnost' $v$ sovremennoj psihologii - Person, subject, personality in modern psychology: Proceedings of the International Conference dedicated to the 80th anniversary of A. V. Brushlinsky, 2, 169-173. Moskva : Izd-vo IP RAN [in Russian].

Karpov, A. V., \& Skitjaeva, I. M. (2002). Psihologija refleksii [Psychology of Reflexion]. Moskva - Jaroslavl' : Avers Press [in Russian].

Kondratenko, L. O. (2017). Psykholohiia pervynnoi shkilnoi neuspishnosti [Psychology of primary school failure]. Chernihiv : Desna Polihraf [in Ukrainian].

Leont'ev, D. A. (2009). Refleksija kak predposylka samodeterminacii [Reflexion as a prerequisite for self-determination]. A. L. Zhuravlev (Ed.). Psihologija cheloveka $v$ sovremennom mire: materialy Vserossijskoj jubilejnoj nauchnoj konferencii, posvjashchennoj 120-letiju so dnja rozhdenija S. L. Rubinshtejna - Human psychology in the modern world: Proceedings of the All-Russian jubilee scientific conference dedicated to the 120 th anniversary of the birth of S. L. Rubinstein, 2, 40-49. Moskva : Izd-vo IP RAN [in Russian].

Litvinov, A. V., \& Ivolina, T. V. (2013). Metakognicija: ponjatie, struktura, svjaz' s intellektual'nymi kognitivnymi sposobnostjami [Metacognition: Concept, structure, association with intellect and cognitive processes]. Sovremennaja zarubezhnaja psihologija - Modern foreign psychology, 3, 59-70. Retrieved from http://psychlib.ru/ mgppu/periodica/SZP032013/szp-0591.htm\# \$p59 [in Russian].

Maksymenko, S. D. (2006). Heneza zdiisnennia osobystosti [Genesis of Personality]. Kyiv : Vydavnytstvo TOV «KMM» [in Ukrainian].

Maksymenko, S. D. (2018). Mekhanizmy rozvytku osobystosti [Mechanisms of personality development]. S. D. Maksymenko, L. A. Onufriieva (Eds.). Problemy suchasnoi psykholohii: Zbirnyk naukovukh prats Kamianets-Podilskoho natsionalnoho universytetu imeni Ivana Ohiienka, Instytutu psykholohii imeni H. S. Kostiuka NAPN Ukrainy Problems of modern psychology: Collection of research papers of $\mathrm{Ka}$ mianets-Podilskyi National Ivan Ohiienko University, G. S. Kostiuk 
Institute of Psychology of NAPS of Ukraine, 40, 7-23. KamianetsPodilskyi : Aksioma. DOI 10.32626/2227-6246.2018-40.7-23 [in Ukrainian].

Maksymenko, S. D. (2011). Psykholohichni mekhanizmy stanovlennia ta zdiisnennia osobystosti [Psychological mechanisms of the formation and implementation of personality]. S. D. Maksymenko, L. A. Onufriieva (Eds.). Problemy suchasnoi psykholohii: Zbirnyk naukovukh prats Kamianets-Podilskoho natsionalnoho universytetu imeni Ivana Ohiienka, Instytutu psykholohii imeni H. S. Kostiuka NAPN Ukrainy - Problems of modern psychology: Collection of research papers of Kamianets-Podilskyi National Ivan Ohiienko University, G. S. Kostiuk Institute of Psychology of NAPS of Ukraine, 11, 3-11. Kamianets-Podilskyi : Aksioma [in Ukrainian].

Musiiaka, N. I. (2018). Rozvytok tvorchoho myslennia yak osobystisnoi determinanty navchalnykh dosiahnen molodshykh shkoliariv [Development of creative thinking as a personal determinant of primary schoolchildren's educational achievements]. S. D. Maksymenko, L. A. Onufriieva (Eds.). Problemy suchasnoi psykholohii: Zbirnyk naukovukh prats Kamianets-Podilskoho natsionalnoho universytetu imeni Ivana Ohiienka, Instytutu psykholohii imeni H. S. Kostiuka NAPN Ukrainy - Problems of modern psychology: Collection of research papers of Kamianets-Podilskyi National Ivan Ohiienko University, G. S. Kostiuk Institute of Psychology of NAPS of Ukraine, 41, 205-217. Kamianets-Podilskyi : Aksioma. DOI 10.32626/22276246.2018-41.205-217 [in Ukrainian].

Ball, H. O., Dryhus, M. T., Musiiaka, N. I., \& Yavorska-Vietrova, I. V. (2015). Stanovlennia osobystisnoi efektyvnosti uchniv $v$ ontohenetychnomu vymiri [Formation of personal effectiveness of students in the ontogenetic dimension]. M. T. Dryhus (Ed.). Kyiv: Pedahohichna dumka [in Ukrainian].

Tatenko, V. O. (2005). Subiektno-vchynkova tradytsiia v reformuvanni osvity [Subjective-action paradigm in reforming education]. S. D. Maksymenko (Ed.). Teoretyko-metodolohichni problemy rozvytku osobystosti $v$ systemi neperervnoi osvity: Materialy metodolohichnoho seminaru APN Ukrainy - Theoretical and methodological problems of personality development in the system of continuous education: Proceedings of the methodological seminar of the AES of Ukraine, 248256. Kyiv [in Ukrainian].

Fenina, O. Ya. (2017). Problema refleksii ta reflektyvnosti osobystosti u stanovlenni profesiinoho samomenedzhmentu [The problem of reflexion and reflectiveness of personality in the development of professional self-management]. Psykholohiia: realnist $i$ perspektyvy: Zbirnyk naukovukh prats $R D H U$ - Psychology: Reality and Prospects: Collection of research papers of $R D N U, 8,286-291$ [in Ukrainian]. 
Furman, A. V. (2017). Svidomist yak peredumova psykholohichnoho piznannia i profesiinoho metodolohuvannia [Consciousness as a prerequisite for psychological knowledge and professional methodology]. Nauka i osvita. Psykholohiia - Science and education. Psychology, 3, 5-10. DOI http://doi.org/10.24195/2414-4665-2017-3-1 [in Ukrainian].

Karelin, A. (Ed.). (1997). Jenciklopedija psihologicheskih testov: Obshchenie, liderstvo, mezhlichnostnye otnoshenija [Encyclopedia of psychological tests: Communication, leadership, interpersonal relations]. Moskva : AST [in Russian].

Forrest, M. E. S. (2008). On becoming a critically reflective practitioner. Health Information and Libraries Journal, 25, Issue 3, 229-232. Retrieved from https://doi.org/10.1111/j.1471-1842.2008.00787.x.

Hacker, D. J., Bol, K., \& Keener, M. C. (2008). Metacognition in Education: A Focus on Calibration. Handbook of Memory and Metacognition. Mahwah, NJ : Lawrence Erlbaum Associated.

Larrivee, B. (2000). Transforming teaching practice: becoming the critically reflective teacher. Reflective Practice, 1, 293-307.

Moon, J. (2004). Reflection in Learning and Professional Development: Theory and Practice. London and New York : Routledge Falmer.

Vachon, B., \& LeBlanc, J. (2011). Effectiveness of past and current critical incident analysis on reflective learning and practice change. Medical Education, 45, Issue 9, 894-904. Retrieved from https://doi. $\operatorname{org} / 10.1111 / \mathrm{j} .1365-2923.2011 .04042 x$.

\section{Яворська-Ветрова Ірина. Особливості розвитку рефлексивності залежно від особистісної ефективності учнів}

\section{АНОТАЦІЯ}

У статmі розглянуто проблему рефлексії як детермінуючого чинника становлення особистості, що забезпечує успіх діяльності, й рефлексивності як механізму становлення особистісної ефективності. Pефлексія визначається як інтегративна властивість і механізм, що дає змогу особистості усвідомити й оцінити свої суб'єктні якості, проаналізувати власне "Я» та на основі особистісно-смислової оцінки своїх потенційних можливостей поставити нові цілі й співставно з ними адекватно коригувати уявлення про себе і свої ставлення до оточуючих. Висвітлено сучасні метакогнітивістичні трактування рефлексії як переосмислення змісту свідомості, що має регулюючі функції.

Проаналізовано дані експериментального дослідження типів рефлексивності, а також властивостей рефлексивності за критерієм спрямованості (інтра- й інтерпсихічна) в учнів різних за ефективніс- 
тю груп на межі переходу від молодшого шкільного до підліткового віку. Констатовано, що учні з високою особистісною ефективністю у стабільні, "некритичні» періоди шкільного життя демонструють достатньо успішне оволодіння здатністю до самоаналізу, саморозуміння, осмислення себе і своїх ставлень з оточуючими. Водночас з'ясовано, що перехідні періоди (від початкової до основної школи, від молодшого шкільного до молодшого підліткового віку) та періоди адаптації викликають деструктивні тенденції, певне "блокування», зниження темпів розвитку рефлексивності, особливо у групах школярів із низькою ефективністю.

Доведено, що інтрапсихічна рефлексія у школярів від 3-го до 6-го класу розвивається більш інтенсивно і конструктивно, ніж інтерпсихічна. Така загальна тенденція спостерігається як у групах учнів із низькою, так і з високою особистісною ефективністю. Показано, що розвиток інтерпсихічної рефлексії інтенсифікується на межі переходу до підліткового віку, про що свідчить збільшення кількості показників середнього і вищого від середнього рівнів цього типу рефлексії, особливо у групах середньо- та високоефективних учнів.

Ключові слова: рефлексія, рефлексивність, особистісна ефективність, інтрапсихічна рефлексія, інтерпсихічна рефлексія, психологічний механізм.

\section{Яворская-Ветрова Ирина. Особенности развития рефлексивности в зависимости от личностной эффективности учащихся}

\section{АННОТАЦИЯ}

В статье рассмотрена проблема рефлексии как детерминирующего фактора становления личности, обеспечивающего успех деятельности, и рефлексивности как механизма становления личностной эффективности. Рефлексия определяется как интегративное качество и механизм, дающий личности возможность осознать и оценить свои субъектные качества, проанализировать собственное "Я» и на основании личностно-смысловой оценки своих потенциальных возможностей поставить новые цели и в соответствии с ними корректировать представления о себе и свои отношения с окружающими. Освещены современные метакогнитивные трактовки рефлексии как переосмысления содержания сознания, имеющего регулирующие функции.

Проанализированы данные экспериментального исследования типов рефлексивности, а также качеств рефлексивности по критерию 
направленности (интра- и интерпсихическая) у учащихся различных по эфрфективности групп на рубеже перехода от младшего школьного к подростковому возрасту. Констатировано, что учащиеся с высокой личностной эффрективностью в стабильные, "некритические» периоды школьной жизни демонстрируют достаточно успешное овладение способностью к самоанализу, самопониманию, осмыслению себя и своих отношений с окружающими. Выявлено, что переходные периоды (от начальной к основной школе, от младшего школьного к подростковому возрасту) и периоды адаптации вызывают деструктивные тенденции, определенное "блокирование», снижение темпов развития рефлексивности, особенно в группах учащихся с низкой эффективностью.

Доказано, что интрапсихическая рефлексия у школьников от третьего к шестому классу развивается более конструктивно и интенсивно, чем интерпсихическая. Такая общая тенденция наблюдается как в группах учащихся с низкой, так и с высокой личностной эффективностью. Показано, что развитие интерпсихической рефлексии интенсифицируется при переходе к подростковому возрасту, о чем свидетельствует увеличение количества показателей среднего и выше среднего уровней этого типа рефлексии, особенно в группах средне- и высокоэффективных учащихся.

Ключевые слова: рефлексия, рефлексивность, личностная эффективность, интрапсихическая рефлексия, интерпсихическая рефлексия, психологический механизм. 